\title{
Studies on the Pathogenesis of
}

\section{Pigment Gallstones in Hemolytic Anemia}

\section{DESCRIPTION AND CHARACTERISTICS OF A MOUSE MODEL}

\author{
Bruce W. Trotman, Seldon E. Bernstein, Kevin E. Bove, and Gary D. Wirt, \\ School of Medicine, University of Pennsylvania, \\ Philadelphia, Pennsylvania 19104; The Jackson Laboratory, Bar Harbor, \\ Maine 04609; and School of Medicine, University of Cincinnati, \\ Cincinnati, Ohio 45202
}

A в S T R A C T The pathogenesis of hemolysis-induced gallstones was studied in mice with a hereditary hemolytic disease called normoblastic anemia (genotype $n b / n b$ ) and in their normal controls (genotype $+/+$ ). Infrared spectroscopy demonstrated that spontaneously formed gallstones from $n b / n b$ mice were nearly identical to stones from patients with chronic hemolysis as the result of sickle cell disease, and both mouse and human stones strikingly resembled synthetic calcium bilirubinate. $57 \%$ of $115 \mathrm{nb} / \mathrm{nb}$ mice, but none of 109 control mice, developed calcium bilirubinate pigment gallstones $(P<0.001)$. The incidence of luminal gallstones in $n b / n b$ mice was both sex and age dependent. Female $n b / n b$ mice formed stones twice as frequently as male $n b / n b$ mice $(P$ $<0.001$ ). Before 6 mo of age neither sex developed stones, but thereafter the incidence of stones increased with age. Neither hematocrit, reticulocyte count, nor total plasma bilirubin values, were useful in distinguishing between $n b / n b$ mice with or without gallstones. In gallbladder bile, $n b / n b$ mice with gallstones had higher concentrations of hydrogen ion, total bilirubin, calcium, and bile acids than $n b / n b$ mice without stones. Although total unconjugated bilirubin was similar in both $n b / n b$ groups, the ionized fraction of unconjugated bilirubin was higher in bile from $n b / n b$ mice without stones than those with stones. In $n b / n b$ mice, neutral mucin plugs and pigment con-

This work was presented in part at the National Meeting of the American Federation for Clinical Research, Washington, D. C., May 1977, and published in abstract form in 1977. Clin. Res. 25: 302A.

The Jackson Laboratory is fully accredited by the American Association for the Accreditation of Laboratory Animal Care.

Received for publication 24 November 1.978 and in revised form 14 February 1.980. centrations were observed histologically in the glandular crypts of the gallbladder in $33 \%$ of $n b / n b$ mice without stones and in $80 \%$ of $n b / n b$ mice with luminal stones. This suggested that luminal pigment stone disease in mice with hemolysis may be preceded by microscopic precipitation of calcium bilirubinate in the glandular crypts of the gallbladder. These precipitates may then migrate into the lumen and grow by accretion.

\section{INTRODUCTION}

The clinical association between gallstone formation and hemolytic anemia in man is well established (1-3). However, the pathogenesis of pigment lithiasis in hemolytic anemia is poorly understood (4). It has been presumed that rapid erythrocyte destruction and subsequent increased bilirubin output and concentration in bile play an important role (4).

In 1965, a new mutation arose spontaneously in a stock of mice maintained by Dr. Katherine Hummel at The Jackson Laboratory and presented the hematologist with a new hereditary hemolytic anemia. Because of the predominance of normoblasts in the peripheral smear, the mutant was called normoblastic and designated genotype $n b / n b(5,6)$, and subsequent studies indicated an intrinsic defect in the erythrocyte membrane (7). We undertook this study (a) to describe this mouse model of chronic hemolytic anemia and pigment lithiasis, (b) to determine the age, sex, hematological and biliary biochemical features of this model, and $(c)$ to evaluate the histological features of the gallbladder in this disorder.

The results of this study show that $(a)$ pigment stones in $n b / n b$ mice with a hereditary hemolytic anemia are similar to human pigment stones consisting of mainly 
calcium bilirubinate, $(b)$ pigment stones in $n b / n b$ mice are age and sex dependent at comparable levels of plasma bilirubin, $(c)$ an increase in hydrogen ion, total bilirubin, and calcium, but a decrease in ionized unconjugated bilirubin in bile, are associated with luminal stone formation, and $(d)$ microscopic pigment (bilirubinate) and mucin concretions in the glandular crypts of the gallbladder precede luminal stone disease.

\section{METHODS}

Animals. The experimental animals consisted of normal control (genotype $+/+$ ) and normoblastic mice, $n b / n b$. The normoblastic anemia $(n b)$ has been extensively inbred on two different inbred strains, WB/Re and C57BL/6J. The animals in this study were $F_{1}$ hybrids produced from these two parent stocks; they were $\mathrm{WBB} \mathrm{F}_{1},+/+$ and $n b / n b$ genotypes. Both types occur as segregants within litters and differ genetically from one another solely in the immediate region of the $n b$ locus. The mutant gene is autosomal recessive with complete penetrance and is not allelic with other hereditary anemias in mice (5).

The anemic mice have a severe intramedullary and intravascular hemolysis, jaundice, hepatosplenomegaly, cardiac hypertrophy, bone marrow hyperplasia, and leukocytosis (5).

Experimental design. This study consisted of two parts. In part A, epidemiological features, bile, stone, and blood parameters were measured; gallbladder histology was obtained in control and $n b / n b$ mice between 4-18 mo of age. In part B, gallbladder bile of control and anemic mice was pooled to measure $\mathrm{pH}$, unconjugated bilirubin, calcium, bile acids, and total bilirubin.

Methods. Mice were fed Lab Blox chow diet Wayne LabBlox, Allied Mills, Inc., Chicago, Ill. After an overnight fast, mice were weighed, then anesthetized with sodium pentobarbital, $0.1 \mathrm{mg} / 10 \mathrm{~g}$ total body wt i.p.

After a midline abdominal incision, the transparent gallbladder was removed and inspected for the presence of gallstones. Bile was collected in 0.5- $\mathrm{ml}$ polystyrene centrifuge tubes on ice and protected from light. In part A, individual bile specimens were obtained except in $20 \%$ of the mice in which specimens from two or three animals were pooled for analyses. Bile from animals with stones was not mixed with bile from those without stones. Blood was collected by cardiac puncture with heparinized 1-ml syringes, centrifuged for $5 \mathrm{~min}$, and the plasma saved. Hematocrits were measured in microcapillary tubes. Blood smears were stained with methylene blue, and the percentage of reticulocytes/ 1,000 erythrocytes was determined. In part B, gallbladder bile of two to four mice was pooled.

Gallbladder bile and plasma were assayed for total bilirubin by the Michaelsson method (8). Total bile acids were measured by a fluorometric modification of Talalay's method (9). Unconjugated bilirubin in bile was first separated from all conjugates of bilirubin on silica gel and then quantitated by diazotization with $p$-iodoaniline reagent as described by Boonyapisit et al. (10). Bile $\mathrm{pH}$ was measured with a microelectrode (Microelectrodes, Inc., Londonderry, N. H.) and calcium by atomic absorption spectrophotometry (11). Gallstones were washed with distilled deionized water, dried, and incorporated into $100 \mathrm{mg}$ of spectral-grade potassium bromide, then pressed into a pellet, analyzed, and quantitated by infrared spectrophotometry (11). Calcium bilirubinate was prepared according to the method of Edwards et al. (12). Calcium in stone was measured on another aliquot of sample (11).
From the measured $\mathrm{pH}$ and the concentration of total unconjugated bilirubin, the concentration of ionized unconjugated bilirubin was calculated, assuming a $\mathrm{pK}_{\mathrm{a}}$ of 7.95 for both carboxyl groups and no cooperative interactions between carboxyl groups (10).

The liver, spleen, heart, and kidneys were removed and weighed. The gallbladder was fixed in neutral formalin and sectioned. Routine staining was performed with hematoxylin and eosin. The presence of neutral or acidic glycoproteins in the gallbladder sections was assessed by staining with the periodic acid Schiff (PAS)' method after digestion with diastase or Alcian blue ( $\mathrm{pH}, 2)$, respectively (13). One of the authors (K.E.B.) interpreted coded histological specimens without prior knowledge of the genotype.

Statistics. Comparisons between groups were made by the Wilcoxon rank sum test. The distribution of mice was assessed by Chi square analysis (14). Primary data were expressed as means \pm SEM.

\section{RESULTS}

Hematological parameters. The mean hematocrits of $n b / n b$ mice with or without gallstones maintained at the University of Pennsylvania were similar (18.8 \pm 0.6 vs. $19.6 \pm 0.5 \% \mathrm{SE}$ ), and each was significantly less than control mice, $43.9 \pm 0.6 \%(P<0.001)$. Because of the marked hemolysis, a similar 20-fold increase in reticulocytosis was present in $n b / n b$ mice with or without stones $(38.1 \pm 1.9$ vs. $42.2 \pm 2.0 \%)$ as compared with control mice $(2.1 \pm 0.2 \%, P<0.001)$. Likewise, the mean plasma bilirubin concentrations were 20 -fold higher in $n b / n b$ mice with or without gallstones (12.5 \pm 1.0 vs. $12.2 \pm 0.6 \mu \mathrm{M}$ ) as compared with control mice $(0.59 \pm 0.1 \mu \mathrm{M}, P<0.001)$. Thus, the degree of anemia, reticulocytosis, or hyperbilirubinemia in $n b / n b$ mice with or without gallstones was similar. However, hemolysis was a necessary prerequisite for stone formation.

Gallstone type and composition. By infrared spectroscopy, gallstones from $n b / n b$ mice were almost identical to those obtained from a patient with sickle cell anemia (Fig. 1). Both the mouse and human stones strikingly resembled synthetic calcium bilirubinate. Characteristically, calcium bilirubinate shows three strong absorption bands in the region of $1,600 \mathrm{~cm}^{-1}$, whereas unconjugated bilirubin has only two bands $(11,12,15-17)$.

Quantitatively, mouse pigment stones $(n=8)$ contained a similar percentage of pigment (bilirubinate) as three stone specimens from patients with sickle cell anemia $(550 \pm 53$ vs. $700 \pm 115 \mu \mathrm{g} / \mathrm{mg}$ dry stone weight, $P>0.05)$, but less calcium $(41.7 \pm 1.8$ vs. $68.9 \pm 12 \mu \mathrm{g} / \mathrm{mg}, P<0.005)$. However, the percentage of calcium to pigment was similar in mouse and human stones $(7.93 \pm 0.53$ vs. $10.3 \pm 2.45 \%, P>0.05)$. The molar and equivalent ratios of calcium to bilirubinate

\footnotetext{
${ }^{1}$ Abbreviations used in this paper: PAS, periodic acid Schiff.
} 


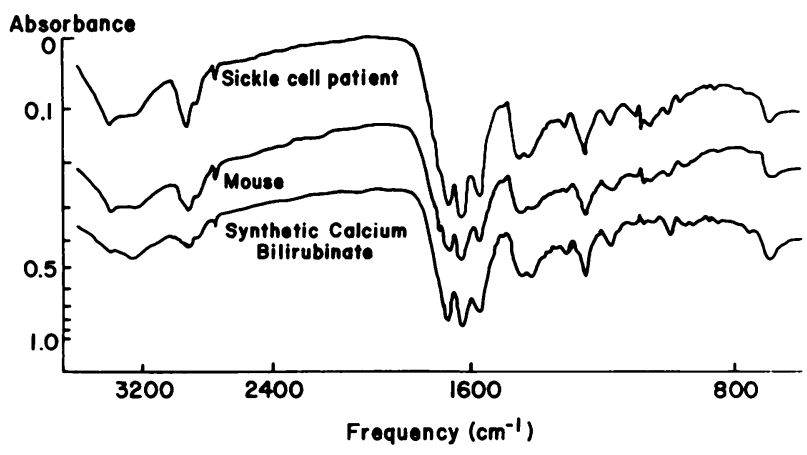

FIGURE 1 Infrared spectra of gallstones from a patient with sickle cell anemia and a $n b / n b$ mouse are similar and both nearly identical to synthetic calcium bilirubinate.

were likewise similar in mouse and human stones $(1.15 \pm 0.08$ vs. $1.50 \pm 0.35 \%, P>0.05)$. Therefore, the chemical analysis and infrared spectra are complementary and indicate that the pigment of both mouse and sickle cell stones is calcium bilirubinate. Calcium in excess of a molar ratio of one suggested that calcium may be associated with stone components other than bilirubinate.

Gallstone incidence. Of $115 \mathrm{nb} / \mathrm{nb}$ mice, $57 \%$ spontaneously developed calcium bilirubinate gallstones, whereas none of 109 controls formed pigment gallstones $\left(\chi_{1}^{2}=P<0.001\right)$, although 3 female controls had nonpigment gallstones. As shown in Fig. 2, the incidence of luminal pigment stones in $n b / n b$ mice was both age and sex dependent. No gallstones were present in either sex of $n b / n b$ mice $<6$ mo of age, but the gallstone incidence increased to $77 \%$ by $7-10 \mathrm{mo}$ in females and to $56 \%$ by 11-14 mo in males, and thereafter remained relatively constant. Overall, gallstones occurred twice as often in the female $n b / n b$ mouse than in the male $\left(\chi_{1}^{2}=P<0.001\right)$.

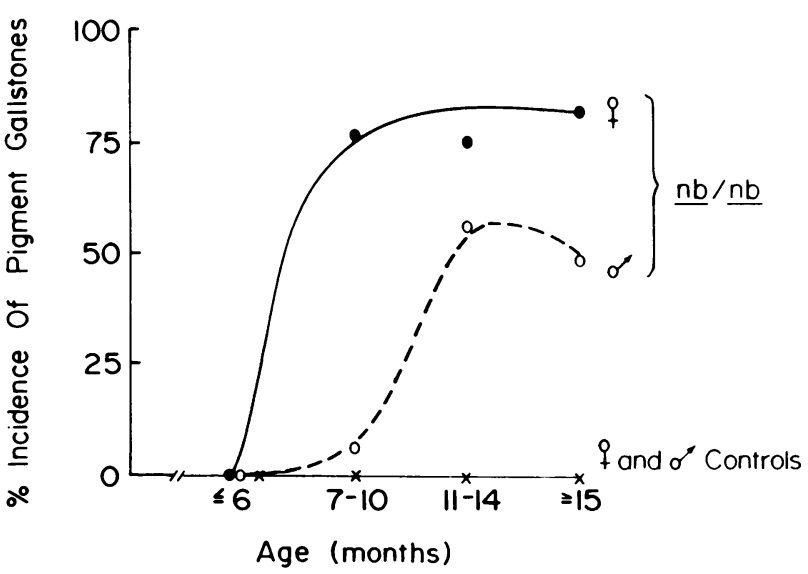

FIgURE 2 Incidence of luminal gallstones in control and $n b / n b$ mice by age and sex. The incidence of stones increased with age and was associated with a female predominance in $n b / n b$ mice. No controls developed pigment gallstones.
Gallbladder bile composition. In bile from all age groups (part A), the mean total bilirubin concentration of $n b / n b$ mice with gallstones $(2,085 \pm 124 \mu \mathrm{M})$ was higher than that of $n b / n b$ mice without stones $(1,727$ $\pm 106 \mu \mathrm{M}, P<0.05)$. Both groups of $n b / n b$ mice had significantly higher gallbladder bilirubin levels than control mice $(221 \pm 15 \mu \mathrm{M}, P<0.001)$. Total bile acids were similar in control mice $(104 \pm 5.5 \mathrm{mM})$ and $n b / n b$ mice with stones $(105 \pm 6.7 \mathrm{mM})$, but significantly lower in $n b / n b$ without stones $(80.0 \pm 7.0 \mathrm{mM}, P$ $<0.001)$.

In part $\mathrm{B}$, the composition of gallbladder bile was further characterized by measuring $\mathrm{pH}$, unconjugated bilirubin, and calcium in control and $n b / n b$ mice of comparable age. As shown in Table I, the hydrogen ion concentration was lowest in $n b / n b$ mice without luminal stones $(9.83 \pm 1.04 \mathrm{nM})$ compared with control mice $(18.7 \pm 2.30 \mathrm{nM}, P<0.05)$ and $n b / n b$ mice with gallstones $(14.2 \pm 0.68 \mathrm{nM}, P<0.05)$. Total unconjugated bilirubin was similar in $n b / n b$ mice with or without stones ( $181 \pm 22$ vs. $214 \pm 26 \mu \mathrm{M}, P>0.05$ ), but was higher than that of control mice $(15.1 \pm 1.30 \mu \mathrm{M}$, $P<0.001)$. The ionized fraction of total unconjugated bilirubin was higher in $n b / n b$ mice without stones than those with stones $(64.7 \pm 9.7$ vs. $38.4 \pm 5.08 \mu \mathrm{M}$, $P<0.05$ ), and that of each $n b / n b$ group was higher than control mice $(2.98 \pm 0.48 \mu \mathrm{M}, P<0.001)$. In contrast, total bilirubin was higher in $n b / n b$ mice with stones than those without stones $(2,879 \pm 202$ vs. $2,357 \pm 162 \mu \mathrm{M}, P<0.05)$, and that of each $n b / n b$ group was higher than control mice $(173 \pm 12 \mu \mathrm{M}, P<0.001)$. Calcium was higher in $n b / n b$ mice with stones $(6.87$ $\pm 0.58 \mathrm{mM})$ than $n b / n b$ mice without stones $(5.23 \pm 0.38$ $\mathrm{mM}, P<0.05)$ and control mice $(4.45 \pm 0.22 \mathrm{mM}, P$ $<0.05)$. Bile acid concentration was similar in $n b / n b$ mice with stones $(132 \pm 10.9 \mathrm{mM})$ and control mice (118 $\pm 8.30 \mathrm{mM}, P>0.05)$, but was significantly lower in $n b /$ $n b$ mice without stones, $(109 \pm 12.1 \mathrm{mM}, P<0.05 \mathrm{com}-$ pared with $n b / n b$ mice with stones.

Gallbladder histology. Gallbladder histology appeared normal in 40 of $51(78 \%)$ control mice, 8 of 18 (44\%) $n b / n b$ mice without pigment gallstones, but in only 3 of $31(10 \%) n b / n b$ mice with stones (Table II). When histochemically analyzed for glycoproteins, PASpositive, diastase-resistant, and Alcian blue-negative mucin (glycoprotein) plugs were located in the glandular crypts of the gallbladder neck glands in the remaining $11(22 \%)$ controls, $10(56 \%) n b / n b$ mice without stones, and $28(90 \%) n b / n b$ mice with stones. Of these 49 mice with mucin plugs, microscopic concretions of yellowish-brown pigment were incorporated into weakly staining PAS-positive mucin in $6(33 \%) n b / n b$ mice without luminal stones and in $25(81 \%) n b / n b$ mice with grossly visible luminal gallstones, but not in control mice (Fig. 3). This suggested that calcium bilirubinate stone formation is initiated in neutral 
TABLE I

Gallbladder Bile Composition of Control $(+++)$ and Normoblastic (nb/nb) Mice

\begin{tabular}{|c|c|c|c|}
\hline Component & $\begin{array}{l}\text { Control }+/+ \\
(n=22)^{*}\end{array}$ & $\begin{array}{c}n b / n b, \text { no pigment stones } \\
(n=14)\end{array}$ & $\begin{array}{c}n b / n b, \text { pigment stones } \\
(n=20)\end{array}$ \\
\hline$\left[\mathrm{H}^{+}\right], n M$ & $18.7 \pm 2.30 \ddagger$ & $9.83 \pm 1.04 \S$ & $14.2 \pm 0.68$ \\
\hline \multicolumn{4}{|l|}{ Total unconjugated } \\
\hline bilirubin, $\mu M$ & $15.1 \pm 1.30$ & $214 \pm 26.0^{\prime \prime}$ & $181 \pm 22.0^{\prime \prime}$ \\
\hline \multicolumn{4}{|l|}{ Ionized unconjugated } \\
\hline bilirubin, $\mu M$ & $2.98 \pm 0.49$ & $64.7 \pm 9.70^{\prime \prime}$ & $38.4 \pm 5.08^{11}$ \\
\hline Total bilirubin, $\mu M$ & $173 \pm 12$ & $2,357 \pm 162^{\prime \prime}$ & $2,879 \pm 202^{11}$ \\
\hline Calcium, $m M$ & $4.45 \pm 0.22$ & $5.23 \pm 0.38$ & $6.87 \pm 0.58 \S \uparrow$ \\
\hline Bile acids, $m M$ & $118 \pm 8.30$ & $109 \pm 12.1$ & $132 \pm 10.99$ \\
\hline
\end{tabular}

$* n$, number of pooled specimens.

$\$$ Mean \pm SE.

$\S P<0.05$ compared with control.

" $P<0.001$ compared with control.

I $P<0.05 n b / n b$, no pigment stones vs. $n b / n b$, pigment stones.

glycoprotein mucin plugs located within the glandular crypts of the gallbladder neck.

Total body and organ weights (Table III). Male and female $n b / n b$ mice with or without gallstones weighed 33 and $26 \%$ less than their respective male or female controls. The relative weights of liver, spleen, heart, and kidneys of all $n b / n b$ mice were significantly higher than control mice. The only difference in relative organ weights noted between $n b / n b$ of each sex with or without stones was that male $n b / n b$ mice with stones had a significant relative increase in kidney mass compared with $n b / n b$ male mice without stones $(P<0.05)$.

TABLE II

Gallbladder Histology in Control $(+/+)$ and Normoblastic (nb/nb) Mice with and without Pigment Gallstones*

\begin{tabular}{lcccc}
\hline & \multicolumn{4}{c}{ Gallbladder histology 1} \\
\cline { 2 - 5 } & Normal & $\begin{array}{c}\text { Mucin plugs } \\
\text { in crypts } \$\end{array}$ & $\begin{array}{c}\text { Pigmented concretions } \\
\text { and mucin plugs } \\
\text { in crypts" }\end{array}$ & Total \\
\hline$+/+$, no PS & 409 & 11 & 0 & 51 \\
$n b / n b$, no PS & 8 & 4 & 6 & 18 \\
$n b / n b$, PS & 3 & 3 & 25 & 31 \\
Total & 51 & 18 & 31 & 100 \\
\hline
\end{tabular}

* Presence of pigment stones (PS) assessed by gross inspection. $\$$ The distribution of gallbladder histology in $+/+$ and $n b / n b$ mice was significantly different: $+/+$ vs. $n b / n b$, no PS $\left(\chi_{2}^{2}\right.$ $=P<0.01) ;+/+$ vs. $n b / n b$, PS $\left(\chi_{2}^{2}=P<0.001\right)$; and $n b / n b$, no PS vs. $n b / n b$, PS $\left(\chi_{2}^{2}=P<0.01\right)$.

$\S$ Mucin plugs were stained positive with PAS reagent and were diastase resistant indicative of neutral glycoproteins.

" Pigmented concretions were yellowish-brown crystalloids incorporated into weakly staining PAS-positive mucin.

I Number of mice.

\section{DISCUSSION}

In the present study, we have demonstrated that $n b / n b$ mice with an inherited form of hemolytic disease called normloblastic anemia spontaneously develop calcium bilirubinate pigment gallstones. Thus, these animals may serve as a useful model of hemolysis-induced gallstones, which are almost identical in composition to those found in a patient with chronic hemolysis (Fig. 1). The advantages of using this animal model to assess factors, such as age, diet, bile flow, and composition on pigment stone formation are obvious because prospective studies in man would take decades to complete and be subject to genetic heterogeneity. Such is not the case with the nb/nb mouse, which is genetically homogeneous, reaches maturity at 2 mo of age, and has a life-span of $\sim 2 \mathrm{yr}$.

Blood parameters. The degree of anemia and bone marrow response in $n b / n b$ mice was assessed by hematocrits and percentage reticulocytosis, respectively; but neither distinguished between affected mice with or without stones. Likewise, the plasma bilirubin concentration was similar between $n b / n b$ mice with or without stones. Although the absolute values for the plasma bilirubin levels were lower than a previously published report (18), the relative differences between control and $n b / n b$ mice remain. In a prior study on spontaneously formed gallstones in mice with hereditary spherocytosis $s p / s p$ (19), it was suggested that ancillary genetic modifiers are responsible for stone formation in the $s p / s p$ mouse because the incidence of stones varied between litters and was totally independent of the genetically determined blood parameters (19).

Gallstone type and incidence. On the basis of morphology, infrared spectroscopy, and chemical analysis, gallstones from $n b / n b$ mice consist pre- 


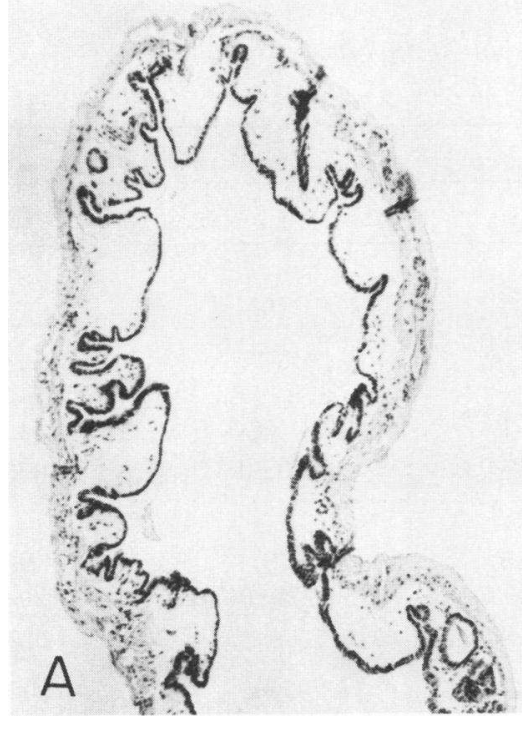

Figure 3 A. Normal gallbladder in control $(+1+)$ mouse. Crypt mucin, although present, is inconspicuous. Hematoxylin and eosin, $\mathrm{H} \& \mathrm{E} \times 75$. B. Gallbladder in $n b / n b$ mouse with intraluminal stones and prominent mucin plugs in crypts, $\mathrm{H} \& \mathrm{E} \times 125$. C. Gallbladder neck glands in $n b / n b$ mouse with luminal stones contain mucin plugs, one of which is heavily stained by bile pigment, $\mathrm{H} \& \mathrm{E} \times 450$.
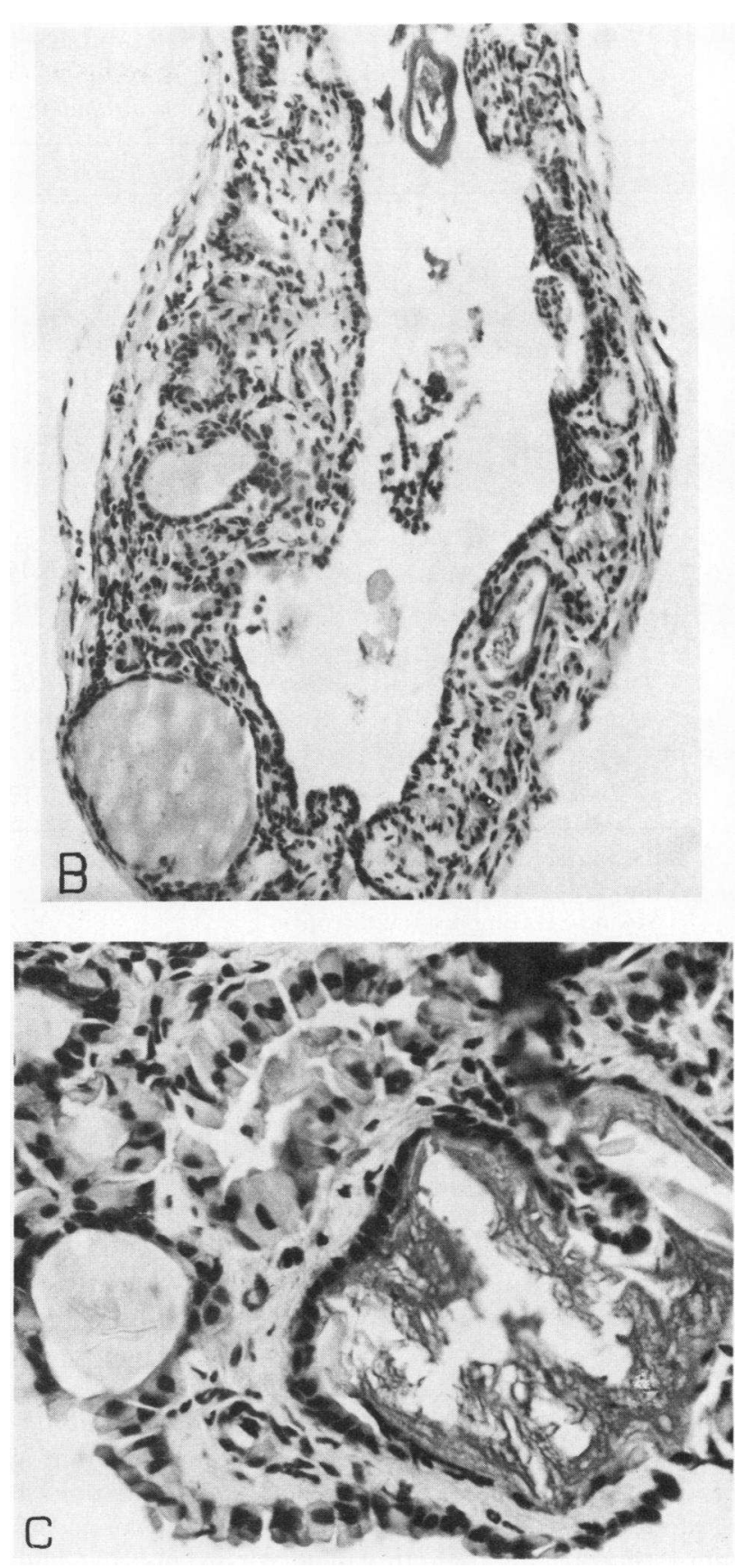

infrared and $x$-ray diffraction studies indicated that such pigment is complexed with calcium $(11,12,15-$ 17). Furthermore, a recent report demonstrated that (a), once solubilized, unconjugated bilirubin can precipitate with calcium over a range of $\mathrm{pH}$ from 6.3-8.4 and (b) that calcium accounted for 3.6-6.2\% of the precipitated calcium bilirubinate depending upon the $\mathrm{pH}$ (17). In the present study, mouse and sickle cell pigment stones had similar molar ratios of calcium to bilirubinate. This, in addition to the 
TABLE III

Total Body and Relative Organ Weights of Control $(+/+)$ and Normoblastic (nb/nb) Mice with or without Pigment Gallstones (PS)*

\begin{tabular}{|c|c|c|c|c|c|}
\hline \multicolumn{3}{|c|}{ Male } & \multicolumn{3}{|c|}{ Female } \\
\hline$+1+$ & $n b / n b$, no PS & $n b / n b$, PS & $+1+$ & $n b / n b$, no PS & $n b / n b$, PS \\
\hline $\begin{array}{c}\text { Total body we } \\
(36) \downarrow \\
39.7 \pm 0.9 \S\end{array}$ & $\begin{array}{c}(16) \\
26.7 \pm 0.6^{\prime \prime}\end{array}$ & $\begin{array}{c}(11) \\
26.6 \pm 0.9^{\prime \prime}\end{array}$ & $\begin{array}{c}(35) \\
31.0 \pm 0.7\end{array}$ & $\begin{array}{c}(8) \\
23.1 \pm 0.6^{\prime \prime}\end{array}$ & $\begin{array}{c}(33) \\
23.6 \pm 0.3^{\prime \prime}\end{array}$ \\
\hline $\begin{array}{c}\text { Liver, \% } \\
\quad(36) \\
4.06 \pm 0.09\end{array}$ & $\begin{array}{c}(16) \\
6.68 \pm 0.27^{\prime \prime}\end{array}$ & $\begin{array}{c}(11) \\
6.62 \pm 0.23^{\prime \prime}\end{array}$ & $\begin{array}{c}(31) \\
4.14 \pm 0.08\end{array}$ & $\begin{array}{c}(8) \\
7.59 \pm 0.31^{\prime \prime}\end{array}$ & $\begin{array}{c}(29) \\
7.20 \pm 0.14^{\prime \prime}\end{array}$ \\
\hline $\begin{array}{c}\text { Spleen, \% } \\
(36) \\
0.211 \pm 0.02\end{array}$ & $\begin{array}{c}(16) \\
6.37 \pm 0.32\end{array}$ & $\begin{array}{c}(11) \\
6.94 \pm 0.35^{\prime \prime}\end{array}$ & $\begin{array}{c}(35) \\
0.270 \pm 0.01\end{array}$ & $\begin{array}{c}(8) \\
8.21 \pm 0.64^{\prime \prime}\end{array}$ & $\begin{array}{c}(33) \\
7.12 \pm 0.19^{\prime \prime}\end{array}$ \\
\hline $\begin{array}{c}\text { Heart, \% } \\
\qquad(36) \\
0.433 \pm 0.01\end{array}$ & $\begin{array}{c}(16) \\
0.864 \pm 0.03^{\prime \prime}\end{array}$ & $\begin{array}{c}(10) \\
0.847 \pm 0.02\end{array}$ & $\begin{array}{c}(21) \\
0.411 \pm 0.01\end{array}$ & $\begin{array}{c}(5) \\
0.866 \pm 0.06^{\|}\end{array}$ & $\begin{array}{c}(18) \\
0.910 \pm 0.05^{\prime \prime}\end{array}$ \\
\hline $\begin{array}{c}\text { Kidney, \% } \\
(29) \\
1.20 \pm 0.04\end{array}$ & $\begin{array}{c}(12) \\
2.38 \pm 0.07\end{array}$ & $\begin{array}{c}(10) \\
2.70 \pm 0.12^{11}\end{array}$ & $\begin{array}{c}(21) \\
1.18 \pm 0.03\end{array}$ & $\begin{array}{c}(5) \\
1.93 \pm 0.08^{\prime \prime}\end{array}$ & $\begin{array}{c}(18) \\
2.12 \pm 0.06^{\prime \prime}\end{array}$ \\
\hline
\end{tabular}

infrared spectral analysis, indicated that calcium bilirubinate was the precipitated salt. The excess of calcium molar equivalents in mouse and sickle cell gallstones of this study was noted in a previous report on pigment stone composition from patients without hemolysis (11). This suggests that calcium salts other than carbonate may be present in these hemolysisrelated stones or that variable molar equivalents of calcium bilirubinate can form depending upon intraluminal events within the gallbladder.

The actual incidence of luminal gallstones in $n b / n b$ mice is age and sex dependent. This suggests that a certain time period is essential for the development of stone disease and that the female $n b / n b$ mouse is more susceptible than the male $n b / n b$ mouse. The female predominance in human cholesterol gallstone disease is well appreciated (21), but not well documented in patients with hemolytic disease (4).

A recent report on gallstones in sickle cell disease showed that $28 \%$ of 206 Jamaican subjects with sickle cell disease had gallstones. The incidence of stones in these patients was more common in the female than male and increased with age (22).

However, in mice with hereditary spherocytosis $s p / s p$ and gallstones, $\sim 20 \%$ of male and female mice develop gallstones, and an appreciable incidence of stones occurs before 3 mo of age (19), whereas no gallstones are present in $n b / n b$ mice of either sex $<6$ mo of age. Thus, it seems likely that conditions conducive to gallstone formation may be modified by a number of genetic, hormonal, or environmental factors.

Gallbladder bile. The initial survey data in part A showed that the mean total bilirubin concentrations of $n b / n b$ mice with gallstones were significantly higher than those of $n b / n b$ mice without stones. Because the mean total bilirubin levels of both $n b / n b$ groups were higher than controls, this indicated that an increased total bilirubin concentration in gallbladder bile was a prerequisite for stone formation, but other factors are also essential to the timing and development of gallstones.

In part B, a more detailed analysis of pooled gallbladder bile was obtained in age-matched $n b / n b$ and control mice. nb/nb mice with stones had significantly higher concentrations of hydrogen ion, total bilirubin, calcium, and bile acids, but less ionized unconjugated bilirubin than $n b / n b$ mice without stones. Interestingly, the total unconjugated bilirubin was similar in bile of $n b / n b$ mice with or without stones. These data suggest that in bile of $n b / n b$ mice with stones the equilibrium of ionized and protonated unconjugated bilirubin was shifted. The small but 
significant increase in hydrogen ion concentration in gallbladder bile of $n b / n b$ mice with stones presumably could result from precipitation of ionized unconjugated bilirubin complexed with calcium. The decrease in ionized unconjugated bilirubin would then shift the equilibrium of protonated and ionized unconjugated bilirubin toward the ionized form with the release of a hydrogen ion. It is likely that these events occur within the gallbladder because stones in the common bile duct are uncommon in $n b / n b$ mice. It is now confirmed that calcium bilirubinate can precipitate from solutions in the physiological $\mathrm{pH}$ range of 7.08.4 (17). Furthermore, the physiochemical properties of unconjugated bilirubin showed a complex interaction of bilirubin and bile acids at $\mathrm{pH} 10$, which, when extrapolated, suggests "micellization" of bilirubin at $\mathrm{pH}$ values below its pKa (23).

The higher bile acid and calcium concentrations in bile of $n b / n b$ mice with stones compared with those without stones is probably related to local gallbladder effects because concentrations of bile acids and calcium in hepatic bile are similar (24). The total bilirubin concentration in gallbladder bile of $n b / n b$ mice with stones was higher than that of those without stones, which is similar to the hepatic bile composition (24).

Morphology. An important observation was the presence of microscopic concretions of pigment associated with neutral glycoprotein (mucin) plugs in crypts of glands located in the gallbladder neck. These microscopic pigment concretions were incorporated into mucin plugs in 6 of $18 \mathrm{nb} / \mathrm{nb}$ mice without visible luminal calculi. In other words, $33 \%$ of the $n b / n b$ mice without luminal stones had the same histological abnormality present in $80 \%$ of $n b / n b$ mice with luminal stones. In fact, this lesion may be the initial microscopic feature of hemolysis-induced pigment gallstone disease in mice. Although mucin was not quantitated in this study, others have demonstrated an increase in mucin production preceding dietary-induced cholesterol stone formation (25-27). A prospective study is indeed necessary to assess the relationship of mucin to other biochemical parameters in bile.

From our studies, we suggest that ionized unconjugated bilirubin in gallbladder bile complexes with calcium and precipitates as calcium bilirubinate within plugs of accumulated mucoprotein. Microscopic stones would then migrate into the lumen and grow by accretion.

\section{ACKNOWLEDGMENTS}

The authors are indebted to the following undergraduate students who provided technical assistance: Susan C. Taylor, Robert A. Martin, and M. Bidi McSorley.

This work was supported by National Institutes of Health grants R01 AM20361, BRSG RR 05415-16, HD00254, and
CA01074. Dr. Trotman was a recipient of a Clinical Investigator Award (K08 AM00235) from the National Institutes of Health (1976-1979).

\section{REFERENCES}

1. Bates, G. C., and C. H. Brown. 1952. Incidence of gallbladder disease in chronic hemolytic anemia (spherocytosis). Gastroenterolog!y. 21: 104-109.

2. Jordan, R. A. 1957. Cholelithiasis in sickle cell disease. Gastroenterology. 33: 952-958.

3. Dewey, K. W., H. Grossman, and V. C. Canale. 1970. Cholelithiasis in thalassemia major. Radiology. 96: 385-388.

4. Soloway, R. D., B. W. Trotman, and J. D. Ostrow. 1977. Pigment gallstones. Gastroenterology. 72: 167-182.

5. Bernstein, S. E. 1969. Hereditary disorders of the rodent erythron. In Genetics in Laboratory Animal Medicine. J. R. Lindsay, editor. National Academy of Science Publication 1724. 9-33.

6. Bernstein, S. E. 1978. Inherited hemolytic disease in mice. Lab. Anim. Sci. In press.

7. Bernstein, S. E. 1972. Chimerism induced by intergenotype transplantation of bone marrow. Exp. Hematol. (Oak Ridge). 1: 69-71.

8. Michaelsson, M. 1961. Bilirubin determination in serum and urine. Scand. J. Clin. Lab. Invest. Suppl. 56: 40-50.

9. Talalay, P. 1960. Enzymatic analysis of steroid hormones. Methods Biochem. Anal. 8: 119-143.

10. Boonyapisit, S. T., B. W. Trotman, J. D. Ostrow, P. J. Olivieri, and D. Gallo. 1976. Measurement of conjugated and unconjugated bilirubin in bile. II. A new chromatographic method. J. Lab. Clin. Med. 88: 857-863.

11. Trotman, B. W., T. A. Morris, III, H. M. Sanchez, R. D. Soloway, and J. D. Ostrow. 1977. Pigment versus cholesterol cholelithiasis: identification and quantification by infrared spectroscopy. Gastroenterology. 72: 495498.

12. Edwards, J. D., Jr., W. D. Adams, and B. Halpert. 1958. Infrared spectrums of human gallstones. Am. J. Clin. Pathol. 29: 236-238.

13. Luna, L. G., editor. 1968. Manual of histological staining methods of the Armed Forces Institute of Pathology. 3rd edition. McGraw-Hill, Inc., New York. 153-157.

14. Croxton, E. 1959. Elementary statistics: With Applications in Medicine and Biological Sciences. Dover Publications, Inc., New York. 1-376.

15. Toyoda, M. 1966. Quantitative determination of calcium bilirubinate in gallstone by infrared spectroscopy. Tohoku J. Exp. Med. 90: 303-316.

16. Chihara, G., S. Yamamoto, and H. Kameda. 1958. Medical and biochemical application of infrared absorption spectra. I. Studies of gallstone by infrared spectra and $x-$ ray crystallography. Chem. Pharm. Bull. (Tokyo). 6: $50-54$.

17. Sutor, J. D., and L. I. Wilkie. 1977. Clin. Sci. Mol. Med. 53: 101-103.

18. Kreimer-Birnbaum, M., R. M. Bannerman, E. S. Russell, and S. E. Bernstein. 1972. Pyrrole pigments in normal and congenitally anemic mice. Comp. Biochem. Physiol. 43A: 21-30.

19. Anderson, R., R. R. Huestis, and A. G. Motulsky. 1966. Hereditary spherocytosis in the deer mouse. Its similarity to the human disease. Blood. 15: 491-503.

20. Soloway, R. D., B. W. Trotman, and W. C. Maddrey. 1978. Similar gallstone composition in patients with and without hemolysis suggests a common etiology. Gastroenterology. 75: 988. (Abstr.) 
21. Heaton, K. W. 1973. The epidemiology of gallstones and suggested aetiology. Clin. Gastroenterology. 2: 67-83.

22. McCall, I. W., P. Desai, B. E. Serjeant, and G. R. Serjeant. 1977. Cholelithiasis in Jamaican patients with homozygous sickle cell disease. Am. J. Hematol. 3: 15-21.

23. Carey, M. C., and A. P. Koretsky. 1979. Self-association of unconjugated bilirubin-IX in aqueous solution at $\mathrm{pH} 10.0$ and physical-chemical interactions with bile salt monomers and micelles. Biochem. J. 178: 675-689.

24. Trotman, B. W., G. D. Wirt, S. E. Bernstein, and K. E. Bove. 1979. Unconjugated bilirubin in hepatic bile of mice with and without pigment gallstones correlates with total bilirubin secretion. Gastroenterology. 76: 1263. (Abstr.)

25. Tepperman, J., F. T. Caldwell, and H. M. Tepperman. 1964. Induction of gallstones in mice by feeding a cholesterolcholic acid diet. Am. J. Physiol. 206: 628-634.

26. Ogato, T., and Y. Nishie. 1974. A scanning electron microscopic study on the formation of cholesterol stones. Tohoku J. Exp. Med. 113: 371-381.

27. Lee, S. P., J. T. LaMont, and M. C. Carey. 1979. Organ culture of the prairie dog gallbladder: increased mucus synthesis and secretion is induced by lithogenic bile. Gastroenterology. 76: 1183 (Abstr.) 